\title{
Is it possible to identify transformational leadership in a financial institution?
}

\author{
Gabriele Girardi
}

PPGA, Universidade do Vale do Rio dos Sinos, São Leopoldo, Brazil and

PPGA, IMED, Passo Fundo, Brazil, and

João Alberto Rubim Sarate

Escola de Administração, UFRGS, Porto Alegre, Brazil

\begin{abstract}
Purpose - The aim of this study is to analyze the perception of employees of a Brazilian financial institution about transformational leadership and, subsequently, compare the results amongst the different groups of respondents.

Design/methodology/approach - The authors present herein an empirical, descriptive and quantitative study, in which the survey was used as the main data collection technique. The survey was applied to a national sample composed of 603 employees (followers) operating in a financial institution. The authors utilized a few statistical techniques to analyze the data collected, namely descriptive statistics, factor analysis, variance analysis and linear regression.

Findings - The results indicate that employees have a high perception toward transformational leadership; no significant differences between the groups of respondents were found. Followers perceive their leader as a transformational agent, who inspires, encourages, considers and motivates them.

Practical implications - The relevance of this research theme and the main findings of this research contribute to managerial practices since the leadership style under investigation is associated with positive outcomes.

Originality/value - This research sought to explore transformational leadership in an unexpected context. The originality of the study relies on the identification of a positive leadership style in the national financial system, which is usually more focused on economic criteria. There is a lack of research on leadership in Brazil, especially when it comes to quantitative studies. Not only the methodology but also the sample representing the entire Brazilian territory bring about the originality of this research.
\end{abstract}

Keywords Leadership, Transformational leadership, Transactional, Financial institutions

Paper type Research paper

\section{Introduction}

The field of leadership studies focuses on the analysis of individuals' and groups' behavior within the organizational context, in addition to the effects of their action in the organization itself. Traditionally, leadership has been understood as a process that influences the activities of a group set to accomplish pre-established goals. Thus, the process of leading is seen as a set of behaviors that allow the manager to influence his/her team (Fonseca, Porto \& BorgesAndrade, 2015).

Leadership can be defined as the practice that influences other people to understand, agree and to do what needs to be done - in other words, an individuals' set of competencies that

(C) Gabriele Girardi and João Alberto Rubim Sarate. Published in Revista de Gestão. Published by Emerald Publishing Limited. This article is published under the Creative Commons Attribution (CC BY 4.0) licence. Anyone may reproduce, distribute, translate and create derivative works of this article (for both commercial and non-commercial purposes), subject to full attribution to the original publication and authors. The full terms of this licence may be seen at http://creativecommons.org/licences/by/4.0/ legalcode

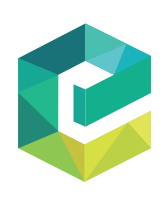

Revista de Gestão Emerald Publishing Limited e-ISSN: $2177-8736$ p-ISSN: $1809-2276$ DOI 10.1108/REGE-12-2020-0141 
gathers followers toward an objective (Yukl, 2002; Pelliciari, 2018). However, the concept of leadership evolves over time, always pursuing improvements in the performance of organizations (Daft \& Pirola-Merlo, 2009). In addition to being a theme internationally investigated for about a century, it is a theme of particular interest to scholars and professionals, especially considering it evolves over time and the lack of good leaders in the world currently (Gil, 2011; Shahid, 2015).

Regarding leadership styles, literature brings several types, such as authoritarian, charismatic, situational, visionary, contingency, behavioral, transactional among others (Avolio, Walumbwa \& Weber, 2009; Dinh et al., 2014; Fonseca et al., 2015). Among the 66 leadership styles indicated by Dinh et al. (2014), transformational leadership (TL) and transactional leadership are the most emphasized, which have been growing rapidly since the 1990s, especially in studies that investigate how these studies promote better performance in organizations (Bass, Avolio, Jung \& Berson, 2003).

Considering the large number of different leadership styles found in literature, TL is the style that will be approached in this research, since it became a central issue in leadership according to scholars and professionals (Bass et al., 2003). Some studies relate TL to other constructs, such as performance, work satisfaction, innovation, beliefs, turnover, ethics, learning, socioenvironmental responsibility, depression, occupational efficacy, motivation, sustainability, commitment, among others (Eliyana \& Ma'arif, 2019; Zuraik \& Kelly, 2019). The theory related to this type of leadership presented results beyond expectations in several studies, with a strong positive impact (Bass, 1998; Avolio, 1999; Pelliciari, 2018). Thus, relating TL to the above-mentioned constructs results in positive outcomes, which justifies the choice of this leadership over the others and leads us to consider it as a positive leadership.

By assessing literature on TL, we verified a lack of research evaluating how employees perceive and identify TL in organizational environments. Fonseca et al. (2015) and Tabassi et al. (2016) affirm that the Brazilian scientific production on leadership is still at its early stage and may be considered obsolete. Regarding TL, despite being one of the most researched leadership styles internationally over the past twenty years, only a few studies were found in Brazil, especially in the banking industry, in which studies have been conducted on mental illness arising from deficient work conditions and stress (Barreto et al., 2013; Fonseca, Porto \& Barroso, 2012; Maciel \& Nascimento, 2013). We chose to further develop this research by investigating TL because it is innovative and promotes individual attention, empowerment of followers and intellectual stimulation (IS), in addition to exerting an idealized influence, stimulating growth and utilizing inspirational motivation (Jung, Chow $\& \mathrm{Wu}, 2003)$.

There is a lack of good leaders (Gil, 2011; Sharid, 2015). According to the World Economic Forum (2015), $86 \%$ of the interviewees agree there is a leadership crisis in the world today. This information confirms the importance of investigating this issue for world economic growth, since there is a need for good leaders for the future. Thus, it is essential and relevant to study and spread awareness of good leadership, which is a characteristic of TL. In addition, there is a lack of this type of leadership in Brazil, which will be further explored later.

As research context, we chose a Brazilian financial institution, which undergoes several regulations, complexities in personnel management, and constant market changes. One may affirm that leadership plays a relevant role to achieve banking strategic objectives.

Considering the research gap previously mentioned and the importance of the theme to literature, our article analyzes the perception of TL in the institution through a descriptive, factor, variance and regression analysis in order to contribute to literature and present practical contributions to the institution under assessment regarding leadership. Therefore, the aim of this study is to analyze the perception of employees of a Brazilian financial institution on TL and compare the results amongst the different groups of respondents. The specific objectives are (1) to assess the perception level of TL in the context studied; (2) to 
identify explanatory factors through factor analysis; (3) to compare factors according to the profile of respondents through variance analysis; and (4) to identify the loading of each construct when determining respondents' general perception about TL.

Recent research indicates growing illness statistics of bank workers (Grisci, 2008; Freitas \& Silva, 2019). Some studies suggest that bank workers' suffering may have reached its peak, which led some professionals to commit suicide (Grisci, Scalco \& Kruter, 2011; Freitas \& Silva, 2019). The causes for such behavior are usually attributed to strict performance requirements and pressure from upper management, which result in irritability, depression, tiredness, discouragement, physical exhaustion, dissatisfaction, lack of motivation, irritation, lack of patience, anxiety, anguish, fear and insecurity (Grisci \& Bessi, 2004; de Freitas \& de Carvalho Silva, 2020). Thus, the current scenario experienced by bank workers in Brazil is insecure and intensifies the suffering and illness of these professionals (Marques \& Giongo, 2016). Even though the aim of our study is not to explore the banking sector, the positive leadership characteristics of TL and the number of studies on the precarious working conditions justify the development of the following hypotheses.

$H 1 a$. There are low levels of transformational leadership in the financial institution.

H1b. There are differences in the perception of transformational leadership among different hierarchical levels and departments.

This research is an empirical, descriptive and quantitative study in which the survey will be used as data collection technique. Previous research carried out by Gyensare, Anku-Tsede, Sanda and Okpoti (2016) on TL will be used as reference to elaborate the questionnaire applied to a national sample of 603 employees of the banking institution. In order to preserve the identity of the company investigated, we adopted the name Bank Research (BR).

\section{Theoretical framework}

Leadership is a dynamic practice, in which the leader's performance changes according to different circumstances and peculiarities (Yukl, 1989; Tabassi et al., 2016). Historically speaking, leadership is essential for the success and survival of organizations and societies, as the leaders' decision influence their direction.

Amongst the leadership styles mentioned in literature, we chose to investigate herein TL, whose origins date back to the classic work of Burns (1978), later expanded by Bass (1990, 1995, 1999, 2003, 2006, 2008, 2013) and Avolio, Walumbra and Weber (2009). Burns presents the differences between TL and transactional leadership considering the relationship between power and leadership. Literature on TL has been gaining more ground since the 1990s, especially on studies that analyze how these types of leadership promote greater performance in organizations (Bass et al., 2003).

Both leaderships represent two points of a continuum (Burns, 1978), in which the transactional leader is a negotiator who establishes arrangements in exchange for desired results and can either reward satisfactory performance or punish for unmet objectives (Fonseca et al., 2012). This type tends to lack results. In contrast, TL achieves superior levels of dedication and performance from employees, in addition to influencing commitment and attitude changes among employees towards the objectives and mission of the institution (Yukl, 1989).

Changes in the labor market over the past years have required leaders to become more transformational (Bass, 1999; Kim, 2014; Buil, Martínez \& Matute, 2019). TL refers to the leader who mobilizes followers going beyond his/her personal interests through idealized influence, IS, inspiration and individualized consideration, elevating the follower's level of maturity, accomplishment and wellbeing of others, of the organization and of society (Bass, 1999). These characteristics provide a sense of work and belonging in the organization and in 
the group. Therefore, transformational leader is the one who stimulates intellectually, inspires, coaches, creates vision and mission, develops cooperation spirit, and is individually considered one of them (Opoku, Ahmed \& Cruickshank, 2015).

Bass (1985a, b) classifies it as a leader who adapts to changes and is flexible; in other words, someone who works more efficiently in rapidly changing business environments. Moreover, TL is the style that enables the transformation of followers, becoming an important asset to face challenges in the competitive, fierce environment characterized currently by constant change and transformation. Thus, the main challenge faced by TL is to align the interests of the organization and its members to achieve the desired objectives in a transformative way (Opoku et al., 2015).

After the emergence of TL in literature, great attention has been paid to understanding how these leaders are better equipped to elevate motivation and performance of followers to higher levels of success (Bass et al., 2003). The leader's behavior is positive and exemplary; it affects the activities of the group while influencing followers, caring for everyone in a comprehensive way and transforming followers by action (Reis, 2015). Due to its peculiarities, TL builds lasting relationships of trust, motivating followers to always seek for better and more consistent results for the organization (Bass \& Riggio, 2013). This is the reason why TL can have a profound effect on followers, since it inspires them to transcend their own interests for the interests of the team and the organization (Robbins, 2009).

The interests of the organization and employees must be aligned (Bass, 1999). The leader must be effective in guiding followers to achieve organizational goals and objectives, increasing the level of team performance (Dionne, Yammarino, Atwater \& Spangler, 2004). TL increases the morale and the motivation of followers, promotes training, creativity and harmony, stimulates followers to achieve high results aligning individual and institutional objectives and goals and provides followers with better orientation, training and support (Bass \& Riggio, 2006; Gumusluoglu \& Ilsev, 2009; Gyensare et al., 2016).

Thus, TL is one of the most influential contemporary approaches of leadership and is characterized by a great load of motivation and rapprochement between leaders and followers (Calaça \& Vizeu, 2015). This occurs because these leaders are proactive, motivate team members to work beyond expectations and raise awareness of the importance of achieving expected goals (Bass and Bass, 2008; Hu, Wang, Liden \& Sun, 2012; Calaça \& Vizeu, 2015).

There are four characteristics inherent in the behavior of transformational leaders (Bass, 1985a, b, 1990, 1999; Bass et al., 2003). The first addresses Idealized Influence (II), in other words, behaviors and attributions of charisma that provide vision and sense of mission, gain of respect and trust, and bring pride to the team. The second characteristic refers to inspirational motivation (IM), which relates to optimism when mobilizing team members, always providing team spirit. IM brings important purposes through simple ways, expressing high expectations and utilizing symbols to focus efforts.

The third item is individualized consideration (IC), which provides individualized attention through counseling, training, and dealing with each employee individually. In TL, support is personalized and guidelines are passed on to followers considering the ability of each one to contribute to the desired results. IS, the fourth characteristic, stimulates intelligence, rationality and is used to carefully solve problems while contributing to the innovativeness and creativity of followers. It also stimulates critical thinking and questions the status quo.

\section{Methodology}

The present study may be considered of quantitative, empirical and descriptive nature; its aim is to investigate the perception of employees (followers) of a Brazilian banking institution 
regarding LT, as well as the difference between different levels of LT in different groups. Moreover, we used the survey as research technique, which consists in applying a structured and self-administered questionnaire to obtain primary data; such technique is based on opinions, attitudes, beliefs, feelings, interests, expectations and other situations experienced by individuals (Malhotra, 2001; Roesch, 2005; Mcdaniel and Gates, 2005; Gil, 2019).

The research population is composed of the set of all collaborators, totaling approximately 100,000 employees of BR, from the strategic to operational level, with intermediary managers at the tactical level (leaders of operational teams). The institution under investigation is present throughout the national territory and is the leader in a few products and services with an average of $20 \%$ share in the national territory $(\mathrm{BCB}, 2018)$. It is worth mentioning that the institution relies on approximately 30,000 leaders with different positions, salaries, attributions and responsibilities.

The population of BR is basically composed of followers, considering they all report to an immediate leader. We chose BR due to its expressiveness in the market and ease of access to respondents. The company had previously authorized the application of the questionnaire, which was forwarded by corporate email to 8,193 employees located in all states of the Brazilian territory. Through data saturation, we confirmed this number to be sufficient to cover the required number of respondents.

We used herein convenience sampling, as we selected the population available to us. According to the definition of non-probabilistic sampling with a $95 \%$ confidence level, it was necessary to reach out to at least 383 respondents. The sample of this article encompasses 603 respondents occupying different positions and in all levels of the institution and located in all states of Brazil; it was not our interest to specify and analyze who the leader was, but to assess the perception of followers regarding the presence of TL at BR.

Thus, we collected primary data through a questionnaire forwarded to employees to obtain a representative sample of BR. Such sample corresponds to followers from every state of the country, working in different positions and units. Data were collected between September and February 2019. Thus, our article represents the leadership of the institution throughout the Brazilian territory.

The instrument developed by Gyensare et al. (2016) on TL served as basis to elaborate the questionnaire that was adapted and applied to BR. We used a five-point Likert scale, in which 1 corresponds to strongly disagree and 5 to strongly agree. The survey used for data collection was structured in two parts:

(1) 17 affirmative sentences related to diverse aspects of TL, conforming to Gyensare et al. (2016); and

(2) A set of questions about general information of the respondent, such as gender, age, occupation, tenure with the institution, educational level among others.

We pretested our survey before the definitive application of questionnaires with a small sample of eight respondents; the aim was to identify and eliminate potential problems, flaws, or inaccuracies in the writing of the questionnaire (Malhotra, 2001; Roesch, 2005; Gil, 2019). After pretesting, small changes were made to clarify a few questions, in addition to the inclusion of relevant suggestions to obtain better results. Table 1 presents the main analytical techniques used according to each objective of the research. The data collected were subsequently analyzed with SPSS software (Statistical Package for the Social Sciences; version 17.0).

The simple regression analysis is a statistical technique that can be used to assess the relationship between one dependent variable and several independent (predictor) variables. Its purpose is to use independent variables, whose values are already known, to predict values of the dependent variable (Hair, Black, Babin, Anderson \& Tatham, 2005). Question 17
Identify
transformational
leadership

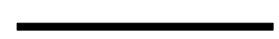


of the questionnaire involved all characteristics of LT in a single question in order to obtain the perception of respondents in a more comprehensive way about the matter, helping to understand how employees understand TL.

In this case, we analyzed the relationship between the dependent variable (Question 17) and other independent variables (II, IM, IC and IS) to identify the relative loading of each factor in determining the general perception of respondents. Question 17 was selected as dependent variable according to the definitions of Jung et al. (2003), who affirm that transformational leader is the one that represents the competence to be followed, stimulates team's learning, motivates individuals, and develops the team. The same way, the four characteristics pointed out by Bass $(1990,1999)$ were also comprised in the same question (II, IM, IC and IS). Therefore this specific question represents not only the general definition of TL, but also its respective factors.

\section{Analysis of results}

As previously mentioned, research about this leadership style in Brazil is still incipient and obsolete when compared to international studies, despite the growing trend of studies on the matter. There is a historical growth of studies about TL in the Web of Science database. However, out of the 4,961 publications mapped since 1999, 2,420 refer to management studies, 1,801 were carried out in the United States, and only 20 in Brazil.

Our research corroborates Fonseca et al. (2015), who affirm that national literature on TL still represents an embryonic field that seems outdated, not only regarding international research, but in relation to other national investigations on organizational behavior. It also confirms that despite being one of the most internationally researched styles in the last 20 years, only a few studies about TL were found in Brazil (Barreto et al., 2013; Fonseca et al., 2012; Maciel \& Nascimento, 2013).

The same occurs in the SCOPUS database, which indicates a recent significant growth on the topic. Out of 4,728 studies found, 1,618 were carried out in the United States and 16 in Brazil. Despite the growing interest in the subject, there is evidence of a lack of research on TL, especially in Brazil, as pointed out in literature. It is also worth mentioning that the Brazilian research found does not portray the same research aim we proposed to achieve herein as it has not been previously addressed by other authors.

\subsection{Assessment of the level of perception of TL through descriptive analysis}

The answers of the respondents were submitted to a descriptive analysis, whose outcomes are presented as follows. The sample is $68.8 \%$ male and $31.2 \%$ female, $50 \%$ of respondents are under 35 years, and $65.2 \%$ have been working for the institution up to 15 years. The most common educational level mentioned by the interviewees were graduate school $(54.7 \%)$,

Table 1. Specific objectives and analytical techniques
Analytical

technique

Descriptive analysis Factor analysis Variance analysis Regression analysis 
complete degree course $(30.3 \%)$, incomplete degree course and high school diploma $(7.8 \%)$ and master's degree and doctorate $(7.1 \%)$. Regarding marital status, $61.3 \%$ of respondents are married, $17.5 \%$ single, $14.4 \%$ married by common law, $6.0 \%$ divorced and $0.7 \%$ widower. Regarding the geographical distribution of respondents throughout the Brazilian territory, $34.4 \%$ of them are from the Southeast, $24.9 \%$ from the South, 17.8 from Central-West, $17.8 \%$ from Northeast and $4.7 \%$ from North.

The respondents were asked to assess the behavior of their immediate leader regarding the requirements inherent in the behavior of a transformational leader (e.g. II, IM, IC and IS). Considering the five-point items for evaluation ranging from 1 to 5 , the average was 3.72 for all questions related to the perception of TL in the institution.

Concerning the answers involving Idealized Influence (II), the average was 3.86. The items related to II refer to questions about respect, trust, influence and authority put by the leader on the group, in addition to displays of interest for the team's wellbeing, the importance of teamwork, and a strong sense of decision making.

The IM, which relates to the leader's optimism and enthusiasm regarding what needs to be done - in addition to a clear vision of the future and faith in the objectives to be achieved - had an average score of 3.91 in the five-point scale, which is the highest score amongst all categories. As for IS, which refers to the leader's incentive to carry out new ways of performing work-related tasks, bringing different perspectives to problems, reassessing his/ her point of view, and analyzing and solving problems from different angles scored 3.73.

Individualized Consideration (IC), meaning the leader's investing time to teach and train followers, to develop strengths and weaknesses, and to provide feedback scored an average of 3.32 in the five-point scale, which is the lowest rating among all TL characteristics. Finally, respondents were asked if the leader could be seen an example of competence, if he/she stimulates team learning, and if he/she invests time in the development of followers; the average score was 3.6.

Thus, after the descriptive analysis of the data collected, one may affirm that answers indicate a predominance of agreement regarding TL characteristics in the institution, including all variables and characteristics previously mentioned. Moreover, respondents perceive high levels of TL in the institution.

\subsection{Identifying explanatory factors of TL through factor analysis}

In order to achieve the second specific objective of this study, we identified the explanatory factors of TL in BR through factor analysis. Thus, the responses of the survey were submitted to principal component analysis with varimax rotation and listwise deletion. When analyzing the responded questionnaires, only a few contained missing values.

The analysis resulted in the four TL factors, as previously seen in Bass $(1990,1999)$ and Gyensare et al. (2016); all variables were grouped exactly as predicted in theory (II, IM, IC, and IS). The explained variance corresponds to $83.23 \%$; several variables presented loadings divided among factors.

The Kaiser-Meyer-Olkin (KMO) test for sampling adequacy was 0.967 , which indicates the sampling is adequate. Bartlett's test of sphericity presented a significance of 0.000 , which indicates a correlation among the variables of the sample researched (Malhotra, 2001).

In addition, the Cronbach's alpha of all factors resulted in a value higher than 0.90 . This indicates a good internal consistency of the variables under investigation since the values of such reliability test should not be less than the interval 0.60-0.70 (Hair et al., 2005). Table 2 , which indicates the analysis of the 603 questionnaires, shows that the variables presented averages ranging from 3.26 to 4.00, with a standard deviation ranging from 1.002 to 1.221 .

Factor 1 - Idealized Influence (II) - grouped the same five variables of the original study, comprising questions Q1-Q5. Factor 2-Inspirational Motivation (IM) also grouped the same four variables of the original study (Gyensare et al., 2016) and of Bass (1985a, b, 1990, 1999),
Identify
transformational
leadership 


\section{REGE}

\begin{tabular}{|c|c|c|c|c|}
\hline Factor & Variable & $\begin{array}{l}\text { Factor } \\
\text { loading }\end{array}$ & $\begin{array}{l}\text { Item } \\
\text { mean }\end{array}$ & $\begin{array}{l}\text { Standard } \\
\text { deviation }\end{array}$ \\
\hline \multirow[t]{5}{*}{$\begin{array}{l}\text { F1-Idealized influence } \\
(0.938)^{*}\end{array}$} & $\begin{array}{l}\text { Q1 - My leader goes beyond self-interest } \\
\text { for the good of the team }\end{array}$ & 0.687 & 3.70 & 1.095 \\
\hline & $\begin{array}{l}\text { Q2 - My leader acts in a way that earns } \\
\text { my respect }\end{array}$ & 0.688 & 3.83 & 1.118 \\
\hline & $\begin{array}{l}\text { Q3 - My leader demonstrates a sense of } \\
\text { authority and trust }\end{array}$ & 0.698 & 3.91 & 1.027 \\
\hline & $\begin{array}{l}\text { Q4 - My leader emphasizes the } \\
\text { importance of having a strong sense of } \\
\text { decision }\end{array}$ & 0.604 & 3.85 & 1.040 \\
\hline & $\begin{array}{l}\text { Q5 - My leader emphasizes the } \\
\text { importance of a sense of teamwork }\end{array}$ & 0.53 & 4.00 & 1.057 \\
\hline \multirow{4}{*}{$\begin{array}{l}\text { F2-Inspirational } \\
\text { motivation } \\
(0.926)^{*}\end{array}$} & $\begin{array}{l}\text { Q6 - My leader is optimistic about the } \\
\text { future }\end{array}$ & 0.830 & 3.90 & 1.034 \\
\hline & $\begin{array}{l}\text { Q7 - My leader shows enthusiasm when } \\
\text { talking about what needs to be done }\end{array}$ & 0.770 & 3.98 & 1.038 \\
\hline & $\begin{array}{l}\text { Q8 - My leader demonstrates that he/she } \\
\text { has a clear vision of the future }\end{array}$ & 0.626 & 3.80 & 1.020 \\
\hline & $\begin{array}{l}\text { Q9 - My leader demonstrates confidence } \\
\text { that goals will be achieved }\end{array}$ & 0.723 & 3.98 & 1.002 \\
\hline \multirow{4}{*}{$\begin{array}{l}\text { F3-Intellectual } \\
\text { stimulation } \\
(0.936)^{*}\end{array}$} & $\begin{array}{l}\text { Q10 - My leader reassesses his/her point } \\
\text { of view }\end{array}$ & 0.647 & 3.67 & 1.113 \\
\hline & $\begin{array}{l}\text { Q11 - My leader looks for different } \\
\text { perspectives when solving problems }\end{array}$ & 0.745 & 3.82 & 1.074 \\
\hline & $\begin{array}{l}\text { Q12 - My leader makes me look at } \\
\text { problems from different angles }\end{array}$ & 0.645 & 3.71 & 1.133 \\
\hline & $\begin{array}{l}\text { Q13 - My leader encourages new ways of } \\
\text { performing work tasks }\end{array}$ & 0.651 & 3.72 & 1.112 \\
\hline \multirow[t]{3}{*}{$\begin{array}{l}\text { F4 - Individualized } \\
\text { consideration }(0.910) *\end{array}$} & $\begin{array}{l}\text { Q14 - My leader spends time teaching } \\
\text { and training me }\end{array}$ & 0.749 & 3.26 & 1.198 \\
\hline & $\begin{array}{l}\text { Q15 - My leader helps me to develop my } \\
\text { strengths and weaknesses }\end{array}$ & 0.755 & 3.40 & 1.171 \\
\hline & $\begin{array}{l}\text { Q16-My leader periodically takes time } \\
\text { to give me feedback and talk about my } \\
\text { work }\end{array}$ & 0.826 & 3.30 & 1.221 \\
\hline \multicolumn{5}{|c|}{$\begin{array}{l}\text { Note(s): *Cronbach's alpha } \\
\text { Source(s): elaborated by authors (2019) }\end{array}$} \\
\hline
\end{tabular}

which are represented by questions Q6-Q9 (Table 2). Factor 3 - Intellectual Stimulation (IS) also grouped the same four variables of the original studies and covers questions Q10-Q13 (Table 2), indicating followers' high perception of IS. Factor 4 - Individualized Consideration (IC) - grouped the same three variables of the original study and comprises questions Q14Q16 (Table 2). This variable indicates that leaders pay attention to every individual need for achievement and growth and act like mentors or coaches (Bass et al., 2003).

Therefore, achieving the specific objective of identifying the explanatory factors of TL, the outcome of factor analysis indicates a grouping of factors the same as those of Gyensare $\mathrm{et} \mathrm{al}$. (2016), corroborating previous literature and theory. No factor loading or mean of the analysis indicated low values, which implicates good levels of perception of TL in the banking institution.

4.3 Comparing TL factors according to respondents' profile through variance analysis

In our study, the analysis of variance (ANOVA) was carried out; this consists in a statistical technique that analyzes the differences among means. The dependent variable (TL) was 
compared with the other independent variables (demographic region, gender, age, function, tenure with the institution, among others).

As result, the ANOVA indicates that only one variable - demographic region - presented a significant difference in one of the explanatory factors of TL (Factor 3 - Intellectual Stimulation), with $p<0,027^{*}$. The Central-West (mean 3.8886) and North (mean 3.8571) regions presented a higher perception of IS; the Southeast region (mean 3.5447) presented the lowest perception.

All other demographic variables presented no significant differences in the four LT factors. One interesting outcome of this study is that the demographic variable was the only one that resulted in differences in the perception of LT (only related to IS); there were no other differences in the perception of TL in the institution.

Considering it is a large company with several functions, departments and worker profiles, it is interesting to mention that in all units - whether large or small agencies, or support departments, or superintendencies and strategic units - and in any workplace there was a balanced perception of TL. In the same way, regardless of the function (director, superintendent, lawyer, clerk or cashier), gender (male and female), age, and educational level, all perceive TL in a homogenous way in the institution. Therefore, the perception of TL does not vary according to the different groups, which already presents itself as a relevant outcome to be reported herein.

\subsection{Identifying the relative loading of each dimension (construct) to determine the general perception of respondents about TL through linear regression}

The four identified factors (II, IM, IS and IC) were treated as independent variables, as for the dependent variable considered was Question 17: "In general, my leader is an example of competence, encourages team learning, and invests time in our development." This variable encompasses all relevant aspects pertaining to TL theory; through these aspects it is possible to assess the general perception of employees on TL.

In the linear regression analysis, variables are considered significant when $p<0.05(5 \%$ margin of error). The beta coefficient is the relative loading of each variable and determines the order of importance of the factors. The $R$-squared $\left(R^{2}\right)$ indicates the explanatory power of a set of independent variables in relation to the dependent variable, in other words, the general perception regarding TL. We applied the stepwise regression (Hair et al., 2005), which utilizes the significance level as entry criteria for variables into the model.

The analysis shows that the model is statistically significant when $p<0,050$ and adjusted $R$-squared equals 0.0764 . Thus, the four factors (II, IM, IS, IC) explain $76.4 \%$ of TL, as indicated in Eqn (1) and Table 2.

$$
\mathrm{LT}=0.392 * \mathrm{II}+0.043 * \mathrm{MI}+0.167 * \mathrm{EI}+0.338 * \mathrm{CI}
$$

The predominant factor is II, with $39.2 \%$; the second is IC, with $33.8 \%$, followed by IS with $16.7 \%$. However, IM could not be considered an explanatory factor as it was not significant (0.270). This way, the above-mentioned factors (II, IC, IS) help to explain TL as result of the regression analysis, except for IM.

In general, the explanation power of TL through the factors reveals that II has the best factor loading, which indicates the existence of a leader that provides vision and sense of mission, introduces pride, gains respects and trust and serves as model for followers, generating willingness to take risks based on ethical and moral conduct. It also means that leaders are respected, admired, trusted and imitated (Bass et al., 2003).

Through this analysis, it is also possible to see that the second factor with the best loading is IC, with $33.8 \%$, which indicates a leadership that provides personal attention, training, 
advising, and treating each employee individually. The third factor in this ranking is IS, with a loading of $16.7 \%$, which relates to leaders that stimulate their followers to create and innovate.

\section{Discussion}

As result of the descriptive analysis, whose specific objective was to evaluate the level of perception of TL by employees of the chosen banking institution, the answers indicate a predominance of agreement regarding the characteristics of TL in the institution considering all variables and characteristics approached (IM, IS, IC and II). Therefore, on a scale from 1 to 5 , the results indicate an average answer of 3.72 for all questions regarding the perception of TL in the institution, which can be considered a high level of perception.

According to the second specific objective of this research, i.e. to identify explanatory factors of TL through factor analysis, the outcomes indicate a grouping of factors precisely the same as those present in Gyensare et al. (2016). In other words, this study grouped the factors as predicted in literature: IS, II, IM and IC. No factor loading or mean of the analysis indicated low values, which indicates good, statistically confirmed perception levels of TL in the institution.

In order to accomplish the third objective of this study, i.e. to compare the four factors of TL according to the profile of respondents, we carried out an analysis of variance, which revealed that only one variable - demographic - presented a significant difference in one of the explanatory factors of TL (Factor 3 - Intellectual Stimulation) in the Central-West (3.89), North (3.86), and Southeast (3.54) regions.

Moreover, such difference may be considered a research finding as respondents from Southeast Brazil have a lower perception of IS than workers from the North and Central-West regions. The Brazilian cultural diversity may have influenced the difference indicated herein. It is worth remembering that IS refers to the leader that encourages intelligence, rationality, and careful problem solving, in addition to helping followers to become more innovative and creative while challenging the status quo. Thus, the perception of such characteristic in the Southeast is lower than in the other demographic regions.

In contrast, another important outcome of ANOVA indicates that only the demographic variable resulted in different perceptions of TL, more specifically regarding the perception of IS. In the other groups - function, gender, age or work unit - we found a homogeneous perception regarding TL. Therefore, the perception of TL does not vary according to the different groups; male or female, junior or senior employee, superintendent, director, clerk, or lawyer operating at any work unit have a homogenous perception of TL at BR. This means that TL seems to permeate the entire organization; it is intrinsic and pervasive through organizational culture.

The linear regression analysis enabled the achievement of the fourth objective of this study; i.e. to identify the relative weight of each dimension to determine the general perception of respondents regarding TL. Thus, it was possible to observe the weight or loading of each factor (IM, IC, IS, and II) treated as dependent variable, which encompass all aspects of TL. As result, the four factors explain $76.4 \%$ of the perception of TL. The predominant factor is II, with $39.2 \%$, followed by IC (33.8\%), and IS (16.7\%). IM, however, was not considered and explanatory factor as it was not significant.

Based on the consistent statistical results presented herein, we conclude there is a high perception of TL within the institution in a homogeneous way between the different groups, which validates all TL factors as presented in literature and explains $76 \%$ of the perception of followers regarding the present of TL in the banking institution. The evidence showed herein indicate that followers perceive their leader as a transformational leader who inspires, encourages, considers and motivates them. 


\section{Conclusion and final considerations}

The present study addresses the characteristic aspects of TL in a large Brazilian financial institution. The research in SCOPUS database on TL research between 1999 and 2018, 4,728 studies were registered; 1,618 from the United States and only 16 from Brazil.

We chose this particular TL style over the others due to the lack of studies in the national context in addition to the necessity to spread knowledge on positive leadership, considering the lack of good political, social, and organizational leaders nowadays. Since good leaders may influence the behavior of their followers in a positive or negative way, it is important to raise awareness about leadership to leverage sustainable social and organizational outcomes.

Through the discussion of the results, we realized a high perception of TL within the institution in a homogeneous way between the different groups, as well as the validation of TL factors precisely according to literature. The hypothesis that predicted low levels of this leadership in a financial institution (H1a), in addition to different perceptions among hierarchical levels and different departments (H1b) had no empirical support. Considering the findings presented herein, the question is: If TL is a good leadership style, how do bank employees perceive them as such? Is it an alienation from the working class? How do employees consider TL as positive leadership when their work environment is typically known for moral harassment and labor complaints?

However, despite the existence of difficult conditions in the labor market, the follower may believe that the leader is in the same working conditions (in the same boat) and considers the leader as an inspiration to be followed. This is explained in literature, as it points that one characteristic of the transformational leader is that he/she is individually considered one of them (Opoku et al., 2015). Nevertheless, it is possible to affirm that in this institution followers to not attribute the responsibility for the working conditions to their immediate manager (those often demanded from unions), even at higher hierarchical levels.

Therefore, there is a work gap to be researched in future studies, i.e. to identify the causes of the existence of illness related to working conditions, such as bullying, sick leave, depression, and - in more serious cases - suicide. We suggest expanding respondents' perception through semi-structured interviews - qualitative research approach - conducted with a group of survey respondents.

Another suggestion for future studies, which will be taken up below, is to identify the concomitant presence of transactional leadership in the institution, since other leadership styles can coexist in the same work environment. Likewise, the present study did not seek to further investigate the leader. For this reason, we also recommend for future study the analysis of what the transformational leader is like, whether men or women are more transformational, etc.

The relevance of the theme and research findings contribute to managerial practices which is the managerial contribution of this research - as TL increases productivity and performance, decreases turnover rates, and promotes greater reach of organizational results and objectives. Therefore, TL is considered an attractive leadership style to be disseminated in companies, given the various positive factors inherent in it.

Since TL can be taught and learned through specific skills and training, it is relevant that organizations are endowed with knowledge about its characterization. In addition to performance in general, leadership promotes sustainable results for the company and tends to influence the alignment of objectives between the organization and the employee.

Thus, the leader can encourage the employee and engage him/her in a mission with common purposes, in addition to a sense of belonging to the company, finding meaning in the workplace, and improving satisfaction. In this way, since these leaders are better equipped to increase motivation and the consequent performance of followers to higher levels of achievement, we consider relevant to disseminate this style of leadership in the culture of organizations.
Identify transformational leadership 
As mentioned previously, there may be other concomitant leadership styles in an organization. In this case, transactional leadership can be considered, which is a leadership with not as much positive aspects as TL (Bass et al., 2003). Transactional leadership derives from transactions, based on positive or negative performances, which can result in benefits for the employee or punishments. That is, followers agree with this leader in exchange for rewards, compliments, or to avoid disciplinary sanctions.

Thus, we assume there may be transactional leadership in the researched institution, based on a recent study in a Brazilian financial institution that found both leaderships (transactional and transformational) in the same institution (Reis, 2015). Therefore, for future research, we recommend this topic to be further investigated in the institution to obtain a more comprehensive perception of leadership. It is noteworthy that transactional also promotes results, but in a way not as positive as transformational. Thus, the company must identify negative leaders and their respective impacts and try to mitigate them, since, in the long term, positive leaders promote greater benefits, satisfaction, retention of talent and engagement in the institution.

As a limitation of the study, we mention the fact that that this study aimed to analyze only the perception of employees regarding the leadership style in the institution. This does not necessarily portray the reality of leadership in the institution, but rather its perception. Indepth exploratory research at the same institution may contribute to advancements of our study.

Thus, the findings of this work can generate academic and managerial contributions, as well as insights for further investigation of the TL concept in different contexts. As practical contributions, the results can encourage reflections on the theme, providing practical actions to improve people management. Socially, good job performance can enhance people's wellbeing and facilitate the ongoing process of community development.

\section{References}

Avolio, B.J. (1999). Full Leadership Development: Building the Vital Forces in Organizations. Thousand Oaks, CA: Sage.

Avolio, B.J., Walumbwa, F.O., \& Weber, T.J. (2009). Leadership: Current theories, research, and future directions. Annual Review of Psychology, 60, 421-449.

Banco Central do Brasil (BCB). Available at: www.bcb.gov.br.Acesso.em.10.abr. 2018.

Bass, B.M. (1985a). Leadership: Good, better, best. Organizational Dynamics, 13(3), 26-40.

Bass, B.M. (1985b). Leadership and Performance Beyond Expectations. New York, NY: Free Press.

Bass, B.M. (1990). From transactional to transformational leadership: Learning to share the vision. Organizational Dynamics, 18(3), 19-31.

Bass, B.M. (1995). Theory of transformational leadership redux. The Leadership Quarterly, 6(4), 463-478.

Bass, B.M. (1998). Transformational Leadership: Individual, Military and Educational Impact. Mahwah, New Jerssey, NJ: Erlbaum.

Bass, B.M. (1999). Two decades of research and development in transformational leadership. European Journal of Work and Organizational Psychology, 8(1), 9-32.

Bass, B.M., \& Bass, R. (2008). The Bass Handbook of Leadership: Theory, Research, and Managerial Applications. 4.ed. New York, NY: Free Press.

Bass, B.M., \& Riggio, R.E. (2006). Transformational Leadership. Mahwah, NJ: Psychology press.

Bass, B.M., \& Riggio, R.E. (2013). Transformational Leadership (2nd ed.). Mahwah, NJ: Psychology press. 
Bass, B.M., Avolio, B.J., Jung, D.I., \& Berson, Y. (2003). Predicting unit performance by assessing transformational and transactional leadership. Journal of Applied Psychology, 88(2), 207.

Buil, I., Martínez, E., \& Matute, J. (2019). Transformational leadership and employee performance: The role of identification, engagement and proactive personality. International Journal of Hospitality Management, 77, 64-75.

Burns, J.M., \& Leadership, H. (1978). Row. New York, NY: Harper and Row, 280.

Calaça, P.A., \& Vizeu, F. (2015). Revisitando a perspectiva de James MacGregor Burns: qual é a ideia por trás do conceito de liderança transformacional?. Cadernos Ebape. BR, 13(1), 121-135.

Daft, R.L., \& Pirola-Merlo, A. (2009). The Leadership Experience. 2nd ed. South Melbourne: Asia Pacific.

Dinh, J.E., Lord, R.G., Gardner, W.L., Meuser, J.D., Liden, R.C., \& Hu, J. (2014). Leadership theory and research in the new millennium: Current theoretical trends and changing perspectives. The Leadership Quarterly, 25(1), 36-62.

Dionne, S.D., Yammarino, F.J., Atwater, L.E., \& Spangler, W.D. (2004). Transformational leadership and team performance. Journal of Organizational Change Management, 17(2), 177-193.

Eliyana, A., \& Ma'arif, S. (2019). Job satisfaction and organizational commitment effect in the transformational leadership towards employee performance. European Research on Management and Business Economics, 25(3), 144-150.

Fonseca, A.M.D.O., Porto, J.B., \& Barroso, A.C. (2012). O efeito de valores pessoais nas atitudes perante estilos de liderança. RAM. Revista de Administração Mackenzie, 13(3), 122-149.

Fonseca, A.M.D.O., Porto, J.B., \& Borges-Andrade, J.E. (2015). Liderança: um retrato da produção científica brasileira. Revista de Administração Contemporânea, 19(3), 290-310.

Gil, A.C. (2019). Métodos e técnicas de pesquisa social (7th ed.). São Paulo, SP: Editora Atlas SA.

Gill, S. (Ed.). (2011). Global Crises and the Crisis of Global Leadership. Cambridge University Press.

Grisci, C.L.I. (2008). Trabalho imaterial, controle rizomático e subjetividade no novo paradigma tecnológico. RAE Eletrônica, 7(1). doi: 10.1590/S1676-56482008000100005.

Grisci, C.L.I., \& Bessi, V.G. (2004). Modos de trabalhar e de ser na reestruturação bancária. Sociologias, (12), 160-200.

Grisci, C.L.I., Scalco, P.D., \& Kruter, G.E. (2011). Dilemas pessoais no trabalho imaterial bancário. Psicologia \& Sociedade, 23(3), 564-573.

Gumusluoglu, L., \& Ilsev, A. (2009). Transformational leadership, creativity, and organizational innovation. Journal of Business Research, 62(4), 461-473.

Gyensare, M.A., Anku-Tsede, O., Sanda, M.A., \& Okpoti, C.A. (2016). Transformational leadership and employee turnover intention. World Journal of Entrepreneurship, Management and Sustainable Development, 12(3), 243-266.

Hair, J.F., Black, W.C., Babin, B.J., Anderson, R.E., \& Tatham, R.L. (2005). Análise multivariada de dados. Porto Alegre, RS: Bookman editora.

Hu, J., Wang, Z., Liden, R.C., \& Sun, J. (2012). The influence of leader core self-evaluation on follower reports of transformational leadership. The Leadership Quarterly, 23(5), 860-868.

Jung, D.I., Chow, C., \& Wu, A. (2003). The role of transformational leadership in enhancing organizational innovation: Hypotheses and some preliminary findings. The Leadership Quarterly, 14(4-5), 525-544.

Kim, H.. (2014). Transformational leadership, organizational clan culture, organizational affective commitment, and organizational citizenship behavior: A case of South Korea's public sector. Public Organization Review, 14(3), 397-417.

Malhotra, N.K. (2001). Pesquisa de Marketing-: Uma orientação aplicada. Porto Alegre, RS: Bookman Editora. Identify
transformational
leadership 
Marques, G.D.S., \& Giongo, C.R. (2016). Trabalhadores bancários em sofrimento: uma análise da literatura nacional. Revista Psicologia Organizações e Trabalho, 16(3), 220-247.

Opoku, A., Ahmed, V., \& Cruickshank, H. (2015). Leadership style of sustainability professionals in the UK construction industry. Built Environment Project and Asset Management, 5(2), 184-201.

Pelliciari, M.R.D.M. (2018) Proposta de diretrizes para capacitação em liderança transformacional para os docentes do ensino superior [Doctoral dissertation], Universidade de São Paulo, São Paulo, SP.

Reis, J.P.C. (2015). A influência do estilo de liderança na construção de relações de confiança em uma instituição financeira [Doctoral dissertation]. Rio de Janeiro, RJ: Fundação Getúlio Vargas.

Robbins (2009). Fundamentos do Comportamento Organizacional. São Paulo: Pearson Prentice Hall.

Roesch, S.M.A. (2005). Projeto de estágio e de pesquisa em administração. 3 ed. São Paulo: Atlas.

Shahid, S.. (2015). Lack of leadership. World Economic Forum.

Tabassi, A.A., Roufechaei, K.M., Ramli, M., Bakar, A.H.A., Ismail, R., \& Pakir, A.H.K. (2016). Leadership competences of sustainable construction project managers. Journal of Cleaner Production, 124, 339-349.

World Economic Forum. Lack of leadership. 2015. Available at: http://reports.weforum.org/outlookglobal-agenda-2015/top-10-trends-of-2015/3-lack-of-leadership/ (accessed 08 November 2018).

Yukl, G. (1981). Leadership in Organizations, 9/e. New York: Pearson Education India.

Yukl, G. (1989). Leadership in Organizations. Englewood Cliffs, New Jerssey, NJ: Prentice Hall.

Zuraik, A., \& Kelly, L. (2019). The role of CEO transformational leadership and innovation climate in exploration and exploitation. European Journal of Innovation Management.

\section{Further reading}

da Silva Barreto, L.M.T., Kishore, A., Reis, G.G., Baptista, L.L., \& Medeiros, C.A.F. (2013). Cultura organizacional e liderança: uma relação possível?. Revista de Administração, 48(1), 34-52.

de Freitas, H.N., \& de Carvalho Silva, S.M. (2020). Qualidade de vida no trabalho: estudo de caso sobre o processo de adoecimento que acomete os bancários. Revista Eletrônica de Ciências Sociais Aplicadas, ISSN 2176-5766, 8(2), 19-57.

de Oliveira Maciel, C., \& Nascimento, M.R. (2013). Em busca de uma abordagem não atomizada para o exame das relações entre liderança transformacional e comprometimento organizacional. Revista de Administração, 48(3), 544-559.

Mcdaniel, C., \& Gates, R. (2005). Fundamentos de Pesquisa de Marketing, 4/e. Rio de Janeiro, RJ: Grupo Gen-LTC.

\section{Corresponding author}

Gabriele Girardi can be contacted at: gabydoutorado@gmail.com; gabigb84@gmail.com

For instructions on how to order reprints of this article, please visit our website:

www.emeraldgrouppublishing.com/licensing/reprints.htm

Or contact us for further details: permissions@emeraldinsight.com 